\title{
EXTENDING HOSPITALITY? HISTORY, COURTS, AND THE EXECUTIVE
}

\author{
Dagmar Soennecken
}

\begin{abstract}
While many consider court involvement in immigration matters a given, in liberal nation-states, there is actually a substantial degree of variation. This chapter revisits two "critical junctures" in the early immigration histories of Canada and Germany to show that institutions and policy legacies are not just historical backdrop, but actually shaped the strategies of political actors, subsequent institutional configurations, and policy options for long periods of time, thereby revealing unintended consequences, as well as alternative paths that the involvement of the courts (and other actors) could have taken.
\end{abstract}

\section{INTRODUCTION}

In liberal nation-states, extending hospitality (and later, the right to stay) to strangers has very much been a legal project. For the most part, the executive employed laws and regulations at their discretion, motivated primarily by foreign policy and economic interests, not to mention racial 
prejudices. Migration law, in this reading, functions as a classic instrument of social control. While the precise extent of this control is much debated (Cornelius, Martin, \& Hollifield, 1994), migration scholars often laud the restraining effect of judicial decisions on governments who pursue an immigration "control" agenda. This effect has become even more pronounced lately whenever migration-related questions intersect with anti-terrorism issues (Benvenisti, 2008). Although some writers note that judicial influence (Joppke, 1999) varies significantly from one country to another and that their jurisprudence has not always been rights-expansive, little systematic research has attempted to explain the extent of this variation (but see Legomsky, 1987).

In this chapter, I argue that despite a growing international rights regime (Jacobson \& Ruffer, 2003), important differences persist among countries in the degree of the judiciary's involvement. These differences have their origins in the dominance of the judiciary-executive relationship in the immigration policy area. This relationship, in turn, is embedded in a political and legal system at the national level that is typically slow to change (Kagan, 1997). By going back to the "stem" of this relationship in two "very different" countries, Canada and Germany (Przeworski \& Teune, 1970), I show how the seeds of this relationship got planted, which ones germinated and which ones could have sprouted if conditions had been different. As Michael McCann (1994) notes, "different legal norms and institutional arenas over time offer varying degrees of opportunity for creative challenge." Law's "role in sustaining traditional hierarchies, and hence in structuring potential strategies for resistance, varies significantly among different terrains of struggle" (p. 9). Understanding these different terrains is particularly important for pro-immigration activists. Although they have continuously tried to influence the politics of belonging, the degree of success they have had varies (e.g., Bibler Coutin, 2000; Calavita, 1998). Making sense of key differences in domestic opportunity structures is thus critical for mobilization and strategizing.

"Going back to the stem" may sound a bit like reading tea leaves. In fact, historic institutionalists have long argued that the sequencing of historical events impacts not only future institutional configurations but also the potential for policy change. Fundamentally, historic institutionalism attempts to "place politics in time" to show that "when things happen ... affects how they happen" (Pierson, 2000b, p. 73). Political actors are not immune to this environment. Previously enacted policies ("policy legacies") have the power to imprint themselves on political actors. As a consequence of this imprinting, some choices become more attractive to actors than 
others at certain points in time and thus influence the actors' goals and priorities (Thelen, 1999, p. 371). However, some choices may also produce unintended consequences, counter-reactions and counter-mobilization. To identify their effects and staying power, "we have to go back and look" (Pierson, 2000a, p. 264).

The chapter is divided into four parts. The first briefly outlines each country's approach to immigration. Canada and Germany have very different traditions for incorporating strangers. One follows a more "liberal" approach, while the other follows the more restrictive, "guest worker" model. The overview is not intended to cover each country's entire migration history and various debates - by highlighting key policy developments and actors as well as changes to the scope of judicial oversight, I suggest that there are powerful "echoes of the past in the present" (Macklin, 2005, p. 77) not likely to disappear any time soon. In the next section, I revisit a critical period close to the "stem" to examine in more detail one of these "echoes" before drawing out the implications of the period. While the Canadian case relies on previously unexamined parliamentary records, the German case draws primarily from Germanlanguage legal scholarship at the time.

We will see that the periods critical to the two countries are studies in contrasts. In the Canadian section of this chapter, I revisit the institution of the ouster (or "privative") clause in 1910, the legal provision that formally restrained the involvement of Canadian courts in immigration matters for decades, even beyond the entrenchment of the Canadian Charter of Rights in 1982. As we will see, its imposition was the result of a clash between courts and the executive and not merely a consequence of Canada's common law heritage. In the section on Germany, I revisit the first period after the entrenchment of its well-known asylum provision into its constitution in 1949. Although the provision is perceived as one of the defining features of the German asylum system, as we shall see, it in fact took decades for its prominence to be established. In the early days, the provision was almost in danger of being completely minimized. Both cases show that the mere presence (or absence) of constitutional rights provisions and a Constitutional Court is not enough to explain differences in judicial involvement. As Charles Epp (1998) put it, bills of right are indeed not selfactivating.

Overall, it is not the purpose of my analysis to merely contextualize moments of judicial intervention. As law and society scholars have demonstrated, "the radiating effect of courts" on the policy-making process is much broader (Galanter, 1983). My primary interest here lies in 
illustrating how policy legacies, institutional configurations, and other political actors (in particular the executive) over time not only shape but also prevent and even delay judicial involvement. As Sherlock Holmes famously said, it is indeed curious why the dog didn't bark. ${ }^{2}$ In particular, I want to highlight the varying significance of executive-level countermobilization, institutional obstacles, and policy-making silences. I conclude by suggestion that this style of historic comparative analysis is not merely an academic exercise. As recent developments in Australia illustrate, it holds important lessons for scholars interested in contemporary migration law and policy-making worldwide.

\section{INCORPORATING STRANGERS IN CANADA VS. GERMANY: TWO VERY DIFFERENT MODELS}

Although Canada and Germany are both federal countries with constitutionally entrenched bills of right and powerful high courts, for migration scholars they represent two very different traditions of incorporating strangers. Germany best represents the restrictive "guest worker" model among European societies (Messina, 2007, p. 16). In this model, hospitality is limited and "guests" are only in the country temporarily. This approach is reflected in its citizenship and naturalization policies, which (despite minor reforms in 2000) continue to give priority to those of German descent (Faist \& Triadafilopolous, 2006). Yet Germany has been a major destination for immigrants, despite not possessing a proactive immigration policy, forcing it to continually grapple with questions of who belongs. Canada follows a more "liberal" approach. Migration represents the largest share of its population growth among settler societies. On the whole, it takes in roughly twice as many permanent migrants per 1000 population and twice as many refugees per capita as the United States (OECD, 2008). Overall, it extends hospitality with the expectation of eventually incorporating the newcomers into its society. This is reflected in government support for various immigrant settlement programs as well as in Canada's continued commitment to its long-standing multiculturalism policy (Bloemraad, 2006).

\section{CANADA}

With an active immigration policy that brings in roughly 250,000 people annually (Canada, 2010), including a relatively large share of refugees 
(roughly $10 \%$ of the annual target, plus another 3-5\% humanitarian admissions), Canada is generally considered a liberal, immigrant-welcoming society (Kymlicka, 1998). Since 1976, immigration targets are annually tabled in the House and subsequently discussed in Parliament. However, Canada, like most settler societies, also has a long history of racism and preferential selection of certain immigrants over others. Before the 1970s, Canada's immigration policy was openly race-based and strongly favored European immigrants. This approach grew out of the desire of "colonial administrators to build in Canada an 'overseas extension' or replica of British society" (Stasiulis \& Jhappan, 1995, p. 97). During this time, cabinet created lists of preferred immigrants through "orders-in-council." These were cabinet documents not debated or discussed in Parliament and remained the government's favorite tool for governing immigration policy for decades. Canada's early refugee policy was an extension of this selectionist and discretionary immigration policy. Indeed, the first groups of refugees admitted en masse to Canada (Hungarians in 1957 and Czechs in 1968) were also admitted via orders-in-council. Eventually an approach to large-scale humanitarian resettlement developed - one that still forms the basis for Canada's refugee policy today (Dirks, 1984). Central to Canada's early immigration and refugee policy was the completely discretionary nature of admission; a newcomer's chances at acceptance were almost entirely dependent on the country's overall approach to immigration. Legal rights or entitlements were largely absent from this process.

What is particularly interesting is that the shift to the frequently admired skills-based "point system" in the mid-1970s occurred without judicial involvement. Moreover, for a long time Canada's much admired refugee program also operated without substantial judicial oversight. The reason for the absence of the courts at these critical moments of policy transformation has not been extensively analyzed. While many classic studies of Canadian immigration only refer to the courts on occasion (Hawkins, 1988; but see Kelley \& Trebilcock, 1998), legal analyses usually point to the substantial degree of deference demanded of them due to the Royal Prerogative (the broad discretionary powers granted to the British monarch whose exercise did not require the prior consent of Parliament and which are now exercised by the Executive), and the traditionally limited degree of judicial oversight over administrative actions - both common law legacies (Dussault \& Borgeat, 1990). As we shall see, while these legacies certainly played an important role in the sidelining of the Canadian courts, they are not a pillow that smothered all judicial involvement. If we revisit an early moment during Canada's immigration history, we witness early pockets of activism, 
opposition, and resistance using the law, long before the passing of Canada's constitutional bill of rights, the Charter of Rights and Freedoms, in 1982. But this early, and albeit limited, activism triggered a judicial "ouster" (or "privative") clause in Canadian immigration legislation that would make it much more difficult to gain access to the courts and mobilize the law for social change. This restrictionist climate prevailed even after the formal institutional obstacle (i.e., the privative clause) was removed in 1967 and access to the courts widened.

Today, a number of decisions by Canadian courts have certainly reverberated far beyond its national borders. The Ward case, for example, is frequently cited as one of the leading cases on the question of what constitutes a "social group" in refugee law and whether a "well founded fear of persecution" (justifying refugee status) could come from a non-state actor (Canada (Attorney General) v. Ward, [1993] 2 SCR, 689). The Supreme Court of Canada (SCC) defined the former broadly and answered "yes" to the latter, leading the way in an ongoing debate regarding the claims of other social groups for protection as well as the role of non-state actors in refugee-producing conflict zones. Most of these cases, however, were written after the entrenchment of the 1982 Canadian Charter of Rights and Freedoms, which added a stronger rights angle to the judicial interpretation of procedural fairness in immigration hearings of previous decades. Still, immigration law (together with taxation) make up the smallest percentage of cases heard annually by Canada's highest court (Soennecken, 2008, p. 199), the SCC making their impact all the more significant. One reason there are so few is that the road to the SCC is steep - claimants must first exhaust two levels of judicial review before the Federal Court of Canada, the court that oversees decisions by the Immigration and Refugee Board (IRB), the administrative tribunal responsible for deciding virtually all immigration matters (except for those already dealt with by visa officers overseas). Cases will only be allowed to proceed up to the appeal division of the Federal Court if the case contains a "serious question of general importance," a restriction not placed on cases dealing with other administrative law matters. "Judicial review" further means that the court cannot substitute its opinion for that of the IRB - it can merely ensure that its decisions were carried out in accordance with the law. Access to both the Supreme and Federal Court is further restricted to claimants who have successfully obtained "leave" (or permission) from the court. Success rates for being granted leave are low, and for winning one's case even lower (Greene \& Shaffer, 1992). Although access to the courts was progressively tightened over the years (a promised appeal on the merits 
is still not implemented at the time of writing), it has in fact been limited for decades.

\section{The 1910 Clash and its Echoes}

Canadian courts first became involved in immigration matters in the late 1800s through requests to review (a) denials of admittance to the country and (b) deportation orders. Government officials at the time considered deportations a purely administrative matter, which meant they were often arbitrary. Deportees were first detained and then examined during a closed hearing before a board of inquiry staffed by immigration officials, without any regard to even minimal due process (Roberts, 1988).

Judicial attitudes were generally in line with those of immigration officials. As Roberts (1988) notes further, "the deportation process was overturned by the courts [only] when the Department got caught being sloppy." Despite the similarity between deportation hearings and criminal proceedings, judgments repeatedly affirmed that the deportees were not entitled to any of the procedural rights commonly granted to criminal defendants, such as the right to hear the case against them. In short, “"deportees' had fewer rights than criminals" (pp. 3, 199).

Events in the years leading up to 1910 changed this cozy relationship between the immigration department and the courts. First, around the time of Canadian Confederation in 1867, a growing numbers of Asian immigrants began to enter Canada. The first substantial groups came from China and Japan, later from India. Chinese were being recruited by West Coast industrialists for the building of the Canadian Pacific Railway (CPR) (Avery, 1995). In an effort to control the migration flows from Asia after the completion of the project in 1885 , the government promptly imposed a "head" tax of $\$ 50$ on Chinese newcomers (through the Chinese Immigration Act of 1885) and negotiated a "gentlemen's" agreement with the Japanese government to temporarily cease migration (Macklin, 2005). ${ }^{3}$ Although both measures lead to temporary reductions in migration flows, intermittent anti-immigrant riots began to break out throughout the country, also targeted at southern and eastern Europeans. At the same time, the country seemed to be sliding into a slight economic depression. From 1905 onward, a number of East Asians, largely from India (and British subjects), also began to arrive in Canada. In 1907, a violent anti-immigrant riot erupted in Vancouver plunging the Liberal government into "the gravest crisis any Dominion government had ever faced on the Pacific Coast" (Avery, 1995, p. 49). These anti-immigrant 
tensions did not ease with the subsequent election of the Conservative Borden government in 1911.

Most importantly for our purposes, politicians and government officials in British Columbia (BC) and in Ottawa during this time period were growing increasingly upset and embarrassed by the defeat of a number of key government measures in the courts. These court challenges were mounted by both businesses, primarily $\mathrm{CP}$, and immigrant activists (Kelley \& Trebilcock, 1998). One important regulation that the courts struck down (or declared "ultra vires") gave immigration officials the power to turn back immigrants who had not arrived in Canada by "continuous passage" (PC 27 (January 8, 1908)). This regulation had specifically targeted immigrants from India since, at the time, there were no direct shipping routes from India to Canada (Sampat-Mehta, 1972). CP took the government to court over that regulation the same year the legislation was passed. In its decision, the BC Supreme Court declared the regulation ultra vires of Parliament (i.e., Parliament had exceeded its jurisdiction) and therefore void (Re. Behari Lal et al. (1908) 13 BCR, 415-16). The decision led to the release of 186 migrants who had arrived from India on the Monteagle. It also caused considerable public and political upheaval. However, it did not lead to any long-term policy change since the government passed a new regulation simply reaffirming the disputed one and at the same time introduced a bill in the House that would make the regulation statutory law. It also successfully pressured CP to cease recruiting East Asian migrants overseas (Buchignani, Indra, \& Srivastiva, 1985).

Nevertheless, Ottawa found itself confronting an increasingly powerful Asian community. Large numbers of South Asians arriving in $\mathrm{BC}$ at the time were British subjects, most of them Sikhs. Many well-educated Sikhs believed they were equal citizens in the British Empire. Canadian immigration and deportation practices infuriated them, and they began to mobilize, resorting to the courts as one means to effect change. In 1909, Hassan Rahim was ordered deported (without a formal hearing, as required by law) and released by order of the court only to be subsequently apprehended (this time with a hearing) and released again, by the order of a higher court (Re Rahim (1909-11), 16 BCR, 469-70; Re Rahim (No. 2) (1909-11), 16 BCR, 471-72). As a result, he became a prominent figure in the East Asian community and subsequently became involved in the wellknown Komagata Maru incident. His case highlighted the gap between the government's arbitrary deportation practices and the law on the books. It also illustrated that even in those early days, individuals could harness the power of the courts (but see Walker, 1997). 
The publicity generated by Rahim and similar cases angered government officials so greatly that they took additional measures that halted almost all South and East Asian immigration to Canada, at least temporarily (Buchignani et al., 1985). More importantly, the immigration minister at the time, Frank Oliver, and others reacted harshly to the courts' repeated interference. In the House of Commons, Oliver repeatedly spoke out against the courts. His remarks underscored the executive's prevailing position visà-vis the courts' role: "If you so frame the law that the right or power of deportation becomes a subject of legal dispute, you might nearly as well not have the power" (Anderson, 2006, p. 360). ${ }^{4}$ Oliver noted further that regarding "the extent to which non-citizens were able to use the courts to challenge the Department [of Immigration]," Canada had been made "a laughing-stock to the world" (Anderson, 2006, p. 291). It was not only politicians who were sharply opposed to judicial interference. As Roberts (1988) notes, it was around this time that the attitudes of immigration officials toward the courts shifted from "casual and unintentional disregard" to a "premeditated intent to deprive the alien ... of his [sic] right to judicial protection" (p. 198). Worried that the government was losing control over its borders, Oliver introduced an amendment to the 1906 Immigration Act that explicitly forbade the courts from reviewing deportation proceedings (this is the "privative clause," noted earlier). ${ }^{6}$ Parliamentary records show that some politicians in the House argued that at least the legal rights for British subjects scheduled for deportation should be upheld, but to no avail. What the Laurier government did offer them was an opportunity to make their case before an immigration board. Although this was an improvement from the previous informal practice which had not offer any opportunity for recourse, many deportations continued to be carried out the old "ad hoc" way (Roberts, 1988). Politically, the boards were an open attempt to keep immigrants away from the courts. According to Oliver: "So, while we are making provision on the one hand for a method of inquiry into each case, on the other hand we do not admit the immigrant to the protection of the courts until he has passed that inquiry" (Anderson, 2006, p. 361). ${ }^{7}$ This official distrust of the courts would continue until the mid-1960s.

These early confrontations between Parliament and the courts set the course for the development of judicial involvement in immigration matters and, eventually, refugee determinations as well. Over the next few decades, reviews of the legality of the admission, detention, and deportation of noncitizens remained the sole window of entry for the courts. The tight dimensions of this window were confirmed in immigration act after 
immigration act, all of which made a point of including the "noninterference" clause. Meanwhile, the denial of due process rights for noncitizens was repeatedly criticized in the House by a variety of voices, ranging from the socialist James Woodsworth in the 1920s to the conservative John Diefenbaker in the 1950s.

What developments then followed that triggered the formal re-entry of the courts into immigration matters? First, the privative clause did not prevent judges from keeping their hand in deportation proceedings through traditional common law remedies (i.e., writs), nor did it prevent them from declaring government legislation ultra vires. For instance, in the Brent case of 1956 (Attorney General (A.G.) v. Brent (1956) SCR, 318), the SCC quashed the deportation order of Kathleen Brent, a U.S. citizen who had been ordered deported based solely on a broadly construed section of an immigration regulation, without any indication of the specific reasons. The court argued that the government had exceeded its authority in delegating such broad powers to the bureaucracy. The government responded by passing detailed immigration regulations that listed "the precise classes of persons who were admissible to Canada." This change, Immigration Minister Fairclough subsequently argued, would not have come about without Brent (Hawkins, 1988).

Second, the mid-1960s saw a shift in the broader immigration paradigm, opening it to considerations of equality and humanitarianism (Triadafilopoulos, 2010). As a consequence, the privative clause was quietly removed in 1967. Meanwhile, other social actors in Canada, among them churches and immigrant groups, were beginning to get through with their demand for greater transparency in refugee and immigration proceedings (or at least appeared to do so), as well as for higher standards of justice (Dirks, 1977). However, most analysts agree that societal groups have not been able to establish a regular policy dialogue with politicians and government officials. As Simmons and Keohane found, groups often serve legitimating functions more so than actually being able to influence the direction of government policy (Simmons \& Keohane, 1992).

Third, difficulties in administering an immigration regime based so strongly on discretion helped push these developments along. Officials, some reports noted, were simply overwhelmed and in need of judicial clarification (Hawkins, 1988). As a consequence, courts began to gain jurisprudential traction on immigration issues, though few cases actually made it to the courts initially. Currently, only 2-3 cases annually (out of roughly 60-708 leave applications granted before the SCC) deal with immigration matters (Soennecken, 2008). But not until the entrenchment of the Charter and the 
Supreme Court's 1985 Singh decision (Singh v. Minister of Employment and Immigration [1985] 1 SCR, 177) did the government concede that existing refugee determination procedures also required a radical overhaul (Nash, 1989). The result was the IRB founded in 1989. To this day, its responsibility ranges from refugee determinations to reviewing deportation orders and immigrant sponsorship denials. However, despite numerous legislative amendments and procedural changes - some currently underway - the essential, quasi-judicial structure of the board put in place in 1989 continues to exist.

\section{Implications}

The 1910 conflict between the courts and the Canadian executive mirrors Christian Joppke's contemporary arguments regarding the potential for clashes between a restrictionist executive anxiously guarding its sovereign turf on the one hand and a judiciary charged with upholding a basic set of rights on the other (Joppke, 1999). What makes this early clash interesting from a comparative perspective is that it occurred at a time when Canada had no constitutionally entrenched bill of rights (the earlier 1960 Canadian bill of rights was a federal statute without constitutional status and is generally considered not to have advanced the cause of human rights substantially). Instead, the courts ("activated" by early immigrants and supportive businesses) reminded politicians of their jurisdictional boundaries by striking down laws based on the doctrine of ultra vires, a classic stand-in for rights-based jurisprudence at the time (Walker, 1997). Although judicial attitudes were generally "in line" with that of immigration officials, at the time their decisions still caused enough political upheaval that they shifted the balance of power in the "political space" that both the courts and the executive occupy (Pierson, 2000a, p. 81). Moreover, the 1910 incident led to an institutional configuration that would formally curb access to the courts and thus judicial involvement until the mid-1960s and ultimately shape their political role up to the present day.

\section{GERMANY}

Despite the absence of a proactive immigration policy, Germany became one of the largest immigration countries in the world in the postwar years. In 2009, 16.9 million individuals of "migratory background" lived in 
Germany. This corresponds to $19.6 \%$ of the total population. Of the 16.9 million, 7.2 million were considered foreigners, representing $8.8 \%$ of the total population (compared to an average of $5 \%$ in the rest of Europe). Turks make up the largest (non-EU) group at 3 million (Bundesamt, 2012). ${ }^{8}$ Naturalization has traditionally been difficult to obtain as citizenship was largely based on German ancestry until legislative changes in 2000 (Faist \& Triadafilopolous, 2006).

Foreigners have traditionally entered Germany through three different routes: through the postwar labor recruitment or "guest worker" program (which operated between 1955 and 1973), through the "repatriation" of persons of ethnic German decent living in Eastern Europe, and, finally, through its unique constitutional asylum provision, which made Germany one of Europe's top asylum destinations. Applications peaked between 1990 and 1992. These pressures subsequently led to a constitutional amendment, which restricted the previously broad right to asylum in two key respects: First, refugees coming from "safe third countries" and those coming from designated "safe countries of origin" could be more easily returned. Second, those who are arriving at airports or without documentation can be deemed "manifestly unfounded" and their applications fast-tracked, limiting their right to appeal (Neuman, 1993). Recently, Germany did experiment with a stream for highly qualified non-EU migrants, though with mixed results (Kolb, 2005).

When it comes to immigration issues, German courts have not only been de facto decision-makers but also major policy-makers (Joppke, 1999). While the wide-ranging review powers of Germany's administrative courts and the strong constitutional rights protections for foreigners - especially their unique constitutional asylum guarantee in Art. 16 of the Basic Law are usually cited as reasons for this judicial dominance (Hailbronner \& Legomsky, 2000), the other reasons are political. Green argues that Germany's usual policy-making style of consensual incrementalism is skewed in three important respects when it comes to immigration (Green, 2004). Katzenstein termed this policy-making style "semisovereign governance" (Katzenstein, 1987) because power is widely dispersed among a range of actors, leading to a fairly decentralized state, vis-à-vis a highly centralized society, with powerful unions and employer organizations. This makes it difficult for the federal government and indeed the Chancellor to unilaterally push through an unpopular policy agenda. Federal government "non-decisions" have driven policy outcomes for immigration more than for other policy areas. Not only that, societal interests became less influential once asylum questions began to dominate the immigration agenda from the 
early 1980s onward (Green, 2004). This political configuration led to courts taking the lead on a number of immigration policy issues over the years.

Germany's local administrative courts have had wide-ranging powers to hear immigration matters since the early days after the Second World War. They can review both questions of fact and law, hear the case de novo, and grant further relief to the state administrative courts and ultimately the Federal Administrative Court, although the two highest administrative court levels both have a variety of leave requirements. Cases alleging a violation of constitutional rights may further be heard (again with leave) by the Federal Constitutional Court (Kommers, 1997). However, many of the well-known "rights-expanding" policy developments typically cited by analysts and marshaled along by the courts did not occur until the mid1970 s to early 1980s, i.e., after the formal stop of Germany's labor recruitment policy in 1973 and at the beginning of the Kohl government period (Neuman, 1990). It was during this period that the Federal Constitutional Court made its landmark rulings on the right to family reunification (e.g., the "Indian" case, BVerfGE 49, 168; 1978) and residency rights for non-citizens (e.g., the "Arab" case, BVerfGE 35, 382; 1973) that were only much later transposed into law, though more quickly incorporated into day-to-day bureaucratic decision-making.

What is more interesting for our purposes is the history of the asylum provision. From today's perspective, it is generally taken for granted that Germany's unique asylum guarantee is the reason for its extensive rights jurisprudence. The asylum "guarantee" came into existence after the Second World War when the drafters of the postwar constitution, usually referred to as the Basic Law, created a unique, constitutionally guaranteed right to asylum: "The politically persecuted enjoy the right to asylum," Art. 16 of the Basic Law passed in 1949 stated (Art. 16 Para. 2, GG, pre 1993 version). The inclusion of this broad right to asylum in the constitution was not an obligation imposed by the Allies on the German drafters, rather it was seen as an act of "redemption and atonement" in the aftermath of the Nazi era. Carlo Schmid, the chair of the Parliamentary Council that drafted the constitution, famously argued that "the granting of asylum is always a question of generosity and if you want to be generous, you must risk being sometimes mistaken .... Perhaps therein lies the dignity of such an act" (Joppke, 1999, p. 86).

The historic origins of the constitutional asylum provisions were repeatedly cited by the Federal Constitutional Court in subsequent years to justify an expansive approach to the granting of asylum. All in all, though other constitutions (including those of France and Italy) also contain a right 
to asylum, the Basic Law's provision stands out because it was subsequently interpreted so broadly by the courts that not only could refugee claimants not be refused at the border, they even had the right to enter with a guaranteed access to the verification of their claim (Wollenschläger \& Becker, 1990). For instance, when the government tried to deport rejected asylum seekers and deem their claims "manifestly unfounded," without a thorough prior investigation (BVerfGE 56, 216), the court ruled (in 1981) that the government violated their constitutional rights by not examining their case in detail. In 1983, it affirmed that asylum seekers had a right to access the courts. This constitutional right in turn required the courts uphold a high standard of review, even in cases deemed manifestly unfounded by the government (BVerfGE 65, 76).

By the time it was amended in 1992, the constitutional asylum guarantee had become the personification of what was wrong with Germany's asylum policy. One prominent legal observer noted that the asylum provision's wording and history read together with subsequent jurisprudence did indeed prevent legislators from passing any legislation restricting the right to asylum, short of a constitutional amendment (Kimminich, 1972). Others argued that the German legislature repeatedly referred to the asylum guarantee to absolve itself of any responsibility for shaping the substance of Germany's asylum policy (and instead merely tinkered with its procedures) (Hailbronner, 1987), implying that there was room to act. "The gravest deficiency [in German foreigner law] is the absolute passivity of the lawmaker [Gesetzgeber], who has stolen himself out of his responsibility for years," another prominent German legal scholar lamented (Joppke, 1999, p. 67). Yet others, among them Heinrich Lummer, a prominent conservative Berlin senator in the 1980s, publicly campaigned against the power of the courts over asylum. In a section of his book (1992) entitled The Paralyzed Parliament - How Our Asylum Law Became Judge-Made Law, he states: "No other parliament in the world has had its ability to act taken away in such an important policy area" (p. 74). More recently, some commentators considered the constitutional amendment in 1992 as an "expression of the executive's deep distrust of the courts" (Bosswick, 2000, p. 51).

Until the late 1980s, however, it was a societal taboo to even suggest amending the constitution. No amendments were formally initiated until 1992, and these only after a series of violent attacks against foreigners and asylum seekers brought together enough politicians of all stripes to finally consider such changes, though even then, it was still not straightforward. The bottom line was that though the Christian Democrats (CDU) under Helmut Kohl had been pushing for an amendment for some time, the 
left-leaning Social Democrats (SPD) refused to endorse it. Only when the violence rose to unprecedented levels and the Conservatives agreed to changes regarding reforms to Germany's citizenship law also under discussions did the SPD change its stance (Green, 2004).

In the end, the constitutional amendment added a number of qualifications to the asylum guarantee, thus allowing the German government to fully implement three key diversion policies, based on recently concluded conventions with its European neighbors (Schuster, 2003). NGOs and other refugee advocates further charge that the constitutional amendment has made it much more difficult to obtain asylum in Germany today (Bosswick, 2000). They argue that the amendment set in motion a more conservative era in the rulings of the Federal Constitutional Court long viewed as more refugee friendly than the Federal Administrative Court (which activists have frequently described as the last bastion of the administration). ${ }^{9}$

Given the prominence and the difficulties of amending the asylum provision, it is interesting that it actually took decades for it to become as politically powerful and symbolic as it did. Even more interestingly, in the first few years after its creation, it was almost completely sidelined by all major actors - the federal government, the courts, and the legal community. Understanding this early period is significant because it tells us much about the way in which new rights are "activated." While Epp (1998) found that the relative strength of national support structures for legal mobilization influenced the four rights revolutions in his study, the following discussion suggests further that in countries where the constitutional entrenchment coincided with a fundamental change in the political regime of the country (as was the case in Germany after the end of the Second World War) even institutional (or structural) conditions for accessing constitutional rights take time to grow. During this formative period, the interaction between courts, academia, and government can be critical for the subsequent scope of a constitutional rights provision.

\section{The Weight of History - Interrupted?}

Germany's first postwar asylum regulation in 1953 (Asylverordnung, AsylVO) already granted refugees access to the courts. Passed the same year as the Geneva Convention, it was initially put in place to rectify the fact that Germany did not yet have a procedure for processing refugee claims, although a significant number of people already required processing at the time (Zimmermann, 1994). However, most of these foreign refugees in the 
1950s and 1960s were considered to be en route overseas. At the time, more important to politicians and the public alike was the fate of the ethnic Germans - those who had been exiled or compelled to flee as a result of the war (the "expellees") (Kanstroom, 1993). While there were initially around 12 million expellees on German territory in 1948, the number of foreign refugees (largely East European) was much smaller (5000 per year in the 1950s and 1960s, up to 8000 per year by the mid-1970s).

The AsylVO also created the Federal Office for the Recognition of Foreign Refugees, an administrative agency reporting to the Ministry of the Interior, which placed it in charge of sorting out the status of refugees who were not considered German. The Federal Office opened in Nuremberg on the site of a former International Refugee Organization (IRO) camp for displaced persons (IRO was the predecessor of UNHCR) (Loescher, 2001). The IRO had initially taken responsibility for non-German refugees and displaced persons (DPs). In 1949, it transferred authority for DPs on German territory to the new German government (Senders, 1996). The local administrative court in Ansbach (Bavaria) and the Upper Administrative Court (appeal court at the state level) in Munich were responsible for dealing with any appeals. Appealing to the Federal Administrative Court and the Federal Constitutional Court was also possible right from the start, although access was limited.

Interestingly, the 1953 asylum regulation did not mention the constitutional asylum provision in Art. 16 at all, referring instead to the Geneva Convention (in conjunction with Art. 119 of the Basic Law, which deals with the repatriation of German refugees and DPs). The government's rationale (contained in the official commentary accompanying the AsylVO) was quite simple - the term "politically persecuted" contained in the constitutional provision was too new and "not clearly defined yet" (Franz, 1963). As a consequence, Art. 16 was only occasionally referred to by local administrators dealing with questions of residency status (Zimmermann, 1994). Early case law also tended to refer to the Geneva Convention and the AsylVO but not to the constitutional provision (Kimminich, 1972). When it did, differences of opinion began to develop that would take decades to undo. The local Administrative Court in Ansbach, for one, simply began to equate the Geneva Convention with Art. 16 but that did not settle the debate upon appeal (Wollenschläger \& Becker, 1990) as the upper administrative courts disagreed and developed their own theory. The jurisprudential trend was it to view the Geneva Convention's definition of political persecution as limiting and modifying that of Art. 16. In short, international law was seen as limiting a domestic constitutional right, 
although the text of Art. 16 itself did not contain a reference to such a limitation.

The Constitutional Court was not given much opportunity to comment on this debate since only two immigration cases reached the Constitutional Court during the first decade governed by the AsylVO (1953-1963). Although the court remarked in one of the two cases that those individuals who did not fit the definition of a refugee under the Geneva Convention may well be protected refugees under Art. 16 Basic Law (BVerfGE 9,174/181), their commentary was considered too brief to change the growing opinion of the lower courts. As one prominent legal scholar remarked - almost in disbelief - the constitutional asylum provision was sidelined (and thus nearly forgotten) during this early period (Kimminich, 1972). This odd situation continued until 1965.

By the time the government formally listed Art. 16 as the foundation for Germany's asylum law (namely in the Foreigner's Act of 1965), a protracted debate on the scope of that article had begun in academic circles. While some legal academics argued that such a constitutional right could not be limited by international law, others fell in line with judicial opinion and argued that there was a difference between those individuals protected by the Geneva Convention and those protected by Art. 16. The matter was not settled until the Federal Administrative Court ruled on the matter in 1975 and again in 1983, each time affirming that the constitutional asylum protection may not be limited by the "lower ranking" convention and that there were no "inherent" limitations in Art. 16 either (Bosswick, 2000, p. 44).

What is remarkable about this debate is the protracted silence of the "legislator" [Gesetzgeber] on these questions (not to mention that of societal actors). While some legal experts argued that the government should get involved, others asserted that it had no place in formally defining what exactly political persecution under Art. 16 meant (Kimminich, 1983). Leaving the matter entirely to the courts to figure out until some consensus had been reached was in fact typical of the government's policy-making style in immigration matters for decades to come - until the amendment of the constitution in 1992. As a result, Germany could easily have ended up with a much more restrictive asylum jurisprudence in the long term, if the initial opinion of some members of the courts (and legal academics) had prevailed during this formative period.

The 1965 Foreigner's Act (Ausländergesetz) finally incorporated a reference to the constitutional provision into legislation and created a new quasi-judicial procedure for assessing refugee claims (specifically, an 
independent jury with one chair and two lay members). Furthermore, it offered rejected claimants an internal appeal option at the Federal Office (before a committee of three) before additional action could be taken up the judicial appeal ladder. Regardless of these procedural changes, the legal debates about the scope of protection offered under Art. 16 vis-à-vis the Geneva Convention remained for years to come. In the end, it was the Constitutional Court's repeated insistence that Art. 16 be interpreted liberally that won the day.

\section{Implications}

Although the framers of the Basic Law had intended Germany's constitutional right to asylum to be interpreted broadly, it took a long period of time for the various legal players, ranging from courts to the legal community, to adopt the spirit of these early constitutional days. Politicians and government policy-makers also remained remarkably silent at the time, likely because these "foreign" refugees (at least prior to the 1970s) were severely outnumbered by the millions of expellees also in the country demanding political attention. The legal disagreements continued even when the number of refugees began to dramatically climb for the first time in the mid-1970s, and again in the early 1980s, politically leading to a series of laws intended to "accelerate" their processing, primarily by limiting their access to the courts (Bosswick, 1995).

By the time the government amended the constitution in 1992, the judiciary had so thoroughly shaped the substance and processes of refugee determinations that no ordinary piece of legislation could rectify the imbalance in the division of labor between the courts and the executive. It ultimately required a constitutional amendment that some say created a cordon sanitaire around Germany. The Federal Constitutional Court, in a trilogy of cases, sanctioned this amendment in 1996 to the surprise of some legal observers (Hailbronner, 1996). A number of judges even visited the Frankfurt airport unannounced prior to the decision, underlining the importance of some aspects of the proposed changes to the court. ${ }^{10}$ Ultimately, as one Constitutional Court judge put it, "we could not go against the societal consensus." 11 In the decision, the court commented on the division of labor between the bureaucracy, the "lawmaker" (i.e., the government broadly understood), and the courts and explicitly granted the government a much broader degree of discretion than ever before. This amounted to a paradigm shift in the relationship between the German executive and the courts. 
Uncovering the protracted debates in the legal community during the formative years of the constitution allows us to contemplate the alternate path that the German asylum guarantee could have taken. For one, it is surprising that the legal community did not refer to the spirit of the founders of the Basic Law sooner. But this presumes more "buy in" into the spirit of atonement than perhaps was present in the judicial community at the time. Considering further that these debates occurred when international law was still in its infancy and the exact definition of political persecution was still very much in flux, it is not quite so surprising that the legal chatter went on for as long as it did. Finally, the legislative choice not to formally comment on or enact major laws in this area for a significant period of time represents a stark contrast to the activist stance of the Canadian executive.

\section{CONCLUSION}

This chapter has highlighted two early periods in the immigration histories of Canada and Germany. If we revisited other critical moments in a similar fashion (the German section already discussed the 1992/1993 juncture) and included additional actors - such as refugee organizations - in the analysis (see Soennecken, 2008), we would not only be able to reconstruct the contested space that key political actors occupied and understand better some of the strategic choices they made but begin to be able to more systematically explain why the courts rose to prominence in certain societies (and during certain times) but not in others.

Fundamentally, although both cases examined here show that law is central to the migration enterprise in the two countries, the Canadian case highlighted a clash between the courts and the executive over who determines the right to belong that was subsequently enshrined in a legislative "ouster" clause, while the German case showcased avoidance and (much later) the reassertion of control over the definition of the same right (to belong) by the executive. Both examples also emphasize that the right to belong to these societies was determined at the center and not at the margins. Yet the passivity of the German executive should not be misconstrued as a general unwillingness to use law to govern belonging. There were numerous pieces of legislation governing refugee determination procedures and, as the discussion further showed, Germany has had extensive legislation for governing the return of its "expellee" population. Similarly, the Canadian courts have remained involved in the "welcoming enterprise" and rendered a number of internationally renowned decisions, 
although much of the day-to-day business of determining belonging has been handed over to government officials together with a quasi-judicial body. The rising importance of quasi-judicial bodies is not unique to immigration as some scholars have suggested (Bogart, 1994). It exposes a larger struggle between the administrative state and the courts over the review of administrative actions.

At a broader level, this chapter illustrates that institutions and policy legacies are not merely historical backdrop. They actively (and in both cases, for long periods of time) shaped the strategies of political actors, subsequent institutional configurations, and policy options. Revisiting these earlier times also gives us a sense of the unintended consequences and alternative paths that the courts (and other actors) could have taken in immigration matters, suggesting we pay closer attention to the moments when institutional configurations congeal and become harder to change.

Comparing such different countries as Canada and Germany is growing increasingly common in the policy-making world. First, policy-makers around the globe are increasingly interested in learning from one another. Parliamentarians and bureaucrats - from mayors to EU officials - now regularly embark on fact-finding missions to other countries, including Canada, to study the governance of immigration or at least commission comparative analyses. Second, human rights activists are progressively building transnational networks to advance their struggles for justice (Keck \& Sikkink, 1998). Third, judges converse more and more across borders, and international courts are gaining in significance (Jackson, Tolley, \& Volcansek, 2010). All of these developments make it clear that law making is increasingly becoming globalized. While academics have debated legal globalization for a long time (Sassen, 1996), these developments highlight the growing political significance of this phenomenon.

Finally, although 1910 seems like a long time ago, both the United Kingdom and Australia recently experienced an attempt by the executive to institute a similar "ouster" clause, though with very different political and institutional consequences (Dauvergne, 2005). In the United Kingdom, a 2003 amendment to the country's asylum legislation introduced by the Blair government proposed ending judicial review to the high courts and replacing it with the decision of a specialized administrative tribunal on immigration and asylum. In March 2004, faced with heavy criticism from activists, opposition MPs, and prominent judges, the government withdrew the bill from the House of Lords (Watts, 2004).

Similarly in Australia in 2001, the Parliament inserted a "privative clause" into its Migration Act wherein judicial review was to be limited to 
exceptional cases. The clause quickly became a matter of public debate and ended up before the High Court of Australia in 2003. In its decision, the court ruled that the Australian Parliament did not have the constitutional right to completely exclude the courts from reviewing asylum matters (Dauvergne, 2005). This more recent example highlights the fact that although the role of the courts in immigration policy-making may be similarly restrained in common law countries, there are important differences in their involvement that cannot be explained by federalism or differences in their constitutional provisions alone (Joppke, 1999). Historic institutionalism offers crucial, supplementary tools and insights to such a comparative enterprise.

\section{ACKNOWLEDGMENTS}

For their constructive feedback, I would like to thank the two anonymous reviewers, Caroline Dufour, Soren Frederiksen, Jennifer Fredette, and Susan Solomon. I am deeply grateful to my interviewees for their openness and Austin Sarat for including me in this volume.

\section{NOTES}

1. Many thanks to one of the anonymous reviewers for this analogy.

2. Ibid.

3. The fee was subsequently increased to $\$ 100$ in 1900 and to $\$ 500$ in 1910 , each time leading to a temporary reduction in migration flows.

4. Citing Canada, House of Commons Debates (HCD) (April 3, 1907), 5719.

5. Citing Canada, HCD (March 2, 1914), 1224.

6. "No court has jurisdiction to review, quash, reverse, restrain, or interfere with any proceeding, decision [...] concerning detention or deportation, "upon any grounds whatsoever' except in cases of Canadian citizens or domiciled immigrants" (Section 23, 1910 amendments to the 1906 Immigration Act). Legal proceedings in Rahim had commenced under the 1906 law.

7. Citing Canada, HCD (January 19, 1910), 2135.

8. Data from Destatis, Germany's Statistical Bureau (Statistisches Bundesamt Deutschland); see http://www.destatis.de

9. This was the unanimous conclusion from a number of interviews I conducted with various NGO activists in 2002. Of course, the bureaucratic officials I interviewed called the Federal Constitutional Court "unrealistic" and even "insane" among other things.

10. Interview with Federal Constitutional Court Judge, 18. Sept, 2002.

11. Ibid. 


\section{DAGMAR SOENNECKEN}

\section{REFERENCES}

Anderson, C.G. (2006). Restricting rights, losing control: immigrants, refugees, asylum seekers, and the regulation of Canada's border, 1867-1988. Unpublished doctoral dissertation. McGill University, Montreal.

Avery, D. H. (1995). Reluctant host: Canada's response to immigrant workers, 1896-1994. Toronto: McClelland and Stewart.

Benvenisti, E. (2008). Reclaiming democracy: The strategic uses of foreign and international law by national courts. American Journal of International Law, 102(2), 241-274.

Bibler Coutin, S. (2000). Legalizing moves: Salvadoran immigrants' struggle for U.S. residency. Ann Arbor, MI: University of Michigan.

Bloemraad, I. (2006). Becoming a citizen: Incorporating immigrants and refugees in the united states and Canada. Berkeley, CA: University of California Press.

Bogart, W. A. (1994). Courts and country: The limits of litigation and the social and political life of Canada. Toronto: Oxford University Press.

Bosswick, W. (1995). Asylum policy and migration in Germany. In F. Heckman \& W. Bosswick (Eds.), Migration policies: A comparative perspective (pp. 305-332). Stuttgart: Ferdinand Enke Verlag.

Bosswick, W. (2000). Development of asylum policy in Germany. Journal of Refugee Studies, 13(1), 43-60.

Buchignani, N., Indra, D. M., \& Srivastiva, R. (1985). Continuous journey: A social history of South Asians in Canada. Toronto: McLelland and Stewart.

Bundesamt, S. (2012). Bevölkerung mit Migrationshintergrund - Ergebnisse des Mikrozensus 2011. Bevölkerung und Erwerbstätigkeit, Wiesbaden.

Calavita, K. (1998). Immigration law and marginality in a global economy: Notes from Spain. Law and Society Review, 32(3), 529-567.

Canada, C.I. (2010). Annual report to parliament on immigration. Ottawa: Citizenship and Immigration Canada.

Cornelius, W. A., Martin, P. L., \& Hollifield, J. F. (1994). Controlling immigration: A global perspective. Stanford, CA: Stanford University Press.

Dauvergne, C. (2005). Humanitarianism, identity and nation: Migration laws of Canada and Australia. Vancouver: UBC Press.

Dirks, G. E. (1977). Canada's refugee policy: Indifference or opportunism? Montreal: McGillQueen's University Press.

Dirks, G. E. (1984). A policy within a policy: The identification and admission of refugees in Canada. Canadian Journal of Political Science, 17(2), 279-307.

Dussault, R., \& Borgeat, L. (1990). 2nd ed.). Administrative law ( (Vol. 4). Toronto: Carswell.

Epp, C. R. (1998). The rights revolution: Lawyers, activists, and supreme courts in comparative perspective. Chicago, IL: University of Chicago Press.

Faist, T., \& Triadafilopolous, T. (2006). Beyond nationhood: Citizenship politics in Germany since unification. Toronto: Munk Centre for International Studies, University of Toronto.

Franz, F. (1963). Asylrecht und Asylverordnung. Deutsches Verwaltungsblatt, 4, 125-133.

Galanter, M. (1983). The radiating effects of courts. In K. D. Boyum \& L. Mather (Eds.), Empirical theories of courts (pp. 117-142). New York, NY: Longman.

Green, S. (2004). The politics of exclusion: Institutions and immigration policy in contemporary germany. Manchester: Manchester University Press. 
Extending Hospitality? History, Courts and the Executive

Greene, I., \& Shaffer, P. (1992). Leave to appeal and leave to commence judicial review in canada's refugee determination system: Is the process fair? International Journal of Refugee Law, 4(1), 71-83.

Hailbronner, K. (1987). Vom Asylrecht zum Asylbewerberrecht: Rechtspolitische Anmerkungen zu einem ungelösten problem. In W. Fürst (Ed.), Festschrift für Wolfgang Zeidler (pp. 919-937). Berlin, Germany: de Gruyter.

Hailbronner, K. (1996). Das Asylrecht nach den Entscheidungen des Bundesverfassungsgerichts. Neue Zeitschrift für Verwaltungsrecht, 15(7), 625-631.

Hailbronner, K., Legomsky, S. (2000, June 14-18). Judicial activism and the role of the courts in expanding rights: Families, illegals and asylum seekers. Paper presented at the conference on Magnet Societies: Immigration in Postwar Germany and the United States, Evangelische Akademie Loccum.

Hawkins, F. (1988). Canada and immigration: Public policy and public concern (2nd ed.). Montreal: McGill-Queen's University Press.

Jackson, D. W., Tolley, M. C., \& Volcansek, M. (Eds.). (2010). Globalizing justice: Critical perspectives on transnational law and the cross-border migration of legal norms. Albany, NY: State University of New York Press.

Jacobson, D., \& Ruffer, G. B. (2003). Courts across borders: The implications of judicial agency for human rights and democracy. Human Rights Quarterly, 25, 74-92.

Joppke, C. (1999). Immigration and the nation-state: The United States, Germany and Great Britain. Oxford: Oxford University Press.

Kagan, R. A. (1997). Should Europe worry about adversarial legalism? Oxford Journal of Legal Studies, 17, 165-183.

Kanstroom, D. (1993). Wer sind Wir Wieder? Laws of asylum, immigration, and citizenship in the struggle for the soul of the new Germany. Yale Journal of International Law, 18, 155.

Katzenstein, P. (1987). Policy and politics in west Germany: The growth of a Semisovereign State. Philadelphia, PA: Temple University Press.

Keck, M. E., \& Sikkink, K. (1998). Activists beyond borders: Advocacy networks in international politics. Ithaca, NY: Cornell University Press.

Kelley, N., \& Trebilcock, M. (1998). The making of the mosaic: A history of Canada's immigration policy. Toronto: University of Toronto Press.

Kimminich, O. (1972). Die Entwicklung des Asylrechts in der Bundesrepublik Deutschland (The development of asylum law in the federal republic of Germany). Juristenzeitung, 27(9), 257-263.

Kimminich, O. (1983). Grundsätzliche Fragen der Entwicklung des Asylrechts in der Bundesrepublik Deutschland. In G. Köfner \& P. Nicolaus (Eds.), Probleme des Asylrechts in der Bundesrepublik Deutschland. München: Kaiser.

Kolb, H. (2005). The German "green card”. Focus Migration: Policy Brief, 3(November). Available at http://www.bpb.de/gesellschaft/migration/dossier-migration/58174/thegerman-green-card

Kommers, D. (1997). The constitutional Jurisprudence of the federal republic of Germany (2nd rev. and exp. ed.). Durham: Duke University Press.

Kymlicka, W. (1998). Finding our way: Rethinking ethnocultural relations in Canada. Toronto: Oxford University Press.

Legomsky, S. (1987). Immigration and the judiciary: Law and politics in Britain and America. Oxford: Oxford University Press.

Loescher, G. (2001). The UNHCR and world politics. Oxford: Oxford University Press. 


\section{DAGMAR SOENNECKEN}

Lummer, H. (1992). Asyl. Ein mißbrauchtes Recht (Asylum. An Abused Right). Frankfurt am Main and Berlin: Ullstein.

Macklin, A. (2005). Can we do wrong to strangers? In D. Dyzenhaus \& M. Moran (Eds.), Calling power to account: Law, reparations, and the Chinese Canadian head tax (pp. 6091). Toronto: University of Toronto Press.

McCann, M. (1994). Rights at work: Pay equity reform and the politics of legal mobilization. Chicago, IL: University of Chicago Press.

Messina, A. (2007). The logics and politics of post-WWII migration to Europe. Cambridge: Cambridge University Press.

Nash, A. (1989). International refugee pressure and the Canadian public policy response. Ottawa: Studies in Social Policy, Institute for Research on Public Policy.

Neuman, G. L. (1990). Immigration and judicial review in the federal republic of Germany. New York University Journal of International Law, 23, 35-85.

Neuman, G. L. (1993). Buffer zones against refugees: Dublin, schengen, and the German asylum amendment. Virginia Journal of International Law, 33, 503.

OECD. (2008). OECD International Migration Statistics, 2008. Retrieved from see http:// oecd.org/publications

Pierson, P. (2000a). Increasing returns, path dependence, and the study of politics. American Political Science Review, 94(2), 251-267.

Pierson, P. (2000b). Not just what, but when: Timing and sequencing in political processes. Studies in American Political Development, 14(Spring), 72-92.

Przeworski, A., \& Teune, H. (1970). The logic of comparative social inquiry. New York, NY: Wiley-Interscience.

Roberts, B. (1988). Whence they came: Deportation in Canada. Ottawa: University of Ottawa Press.

Sampat-Mehta, R. (1972). International barriers. Ottawa: Harpell's Press.

Sassen, S. (1996). Losing control? Sovereignty in an age of globalization. New York, NY: Columbia University Press.

Schuster, L. (2003). The use and abuse of political Asylum in Britain and Germany. London: Frank Cass.

Senders, S. (1996). Laws of belonging: Legal dimensions of national inclusion in Germany. New German Critique, 67, 147-176.

Simmons, A. B., \& Keohane, K. (1992). Canadian immigration policy: State strategies and the quest for legitimacy. Canadian Review of Sociology \& Anthropology, 29(4), 421-452.

Soennecken, D. (2008). The growth of judicial power over the fate of refugees: A comparison of Canada and Germany. Unpublished Doctoral Dissertation. University of Toronto, Toronto.

Stasiulis, D., \& Jhappan, R. (1995). The fracticious politics of a settler society: Canada. In D. Stasiulis \& N. Yuvat-Davis (Eds.), Unsettling settler societies: Articulations of gender, race, ethnicity and class (pp. 95-131). London and Thousand Oaks, CA: Sage.

Thelen, K. (1999). Historic institutionalism in comparative politics. Annual Review of Political Science, 2, 369-404.

Triadafilopoulos, T. (2010). Global norms, domestic institutions and the transformation of immigration policy in Canada and the US. Review of International Studies, 36, 169-194.

Walker, J. W. S. G. (1997). "Race," rights and the law in the supreme court of Canada: Historical case studies. Toronto: The Osgoode Society for Canadian Legal History and Wilfrid Laurier University Press. 
Extending Hospitality? History, Courts and the Executive

Watts, N. (2004). Reprieve for asylum appeals. The Guardian (online edition), March 16.

Wollenschläger, M., \& Becker, U. (1990). 40 Jahre Asylgrundrecht - Rückblick und Ausblick. Archiv des öffentlichen Rechts, 115(3), 369-399.

Zimmermann, A. (1994). Das neue Grundrecht auf Asyl: Verfassungs- und völkerrechtliche Grenzen und Voraussetzungen (Vol. 115). Berlin: Springer Verlag.

\section{CASES CITED}

Canada (Attorney General) v. Ward, [1993] 2 SCR, 689.

Re. Behari Lal et al. (1908) 13 BCR, 415-16.

Re Rahim (1909-11), 16 BCR, 469-70; Re Rahim (No. 2) (1909-11), 16 BCR, 471-72.

Attorney General (A.G.) v. Brent (1956) SCR, 318.

Singh v. Minister of Employment and Immigration [1985] 1 SCR, 177.

Entscheidungen des Bundesverfassungsgerichts [BverfGE] [Federal Constitutional Court] 49, 168; 1978 ("Indian" case).

BVerfGE 35, 382; 1973 (“Arab" case).

BVerfGE 56, 216.

BVerfGE $65,76$.

BVerfGE 9,174/181.

\section{Constitutional and Statutory Provisions Cited}

Canadian Charter of Rights and Freedoms, Part I of the Constitution Act, 1982, being Schedule B to the Canada Act 1982 (U.K.), 1982, c. 11.

Chinese Immigration Act 1885, c. 71.

Grundgesetz der Bundesrepublik Deutschland (GG) [Constitution](F.R.G.).

Asylverordnung [AsylVO] [Asylum Regulation] (1953).

Ausländergesetz [AuslG] [Foreigner's Act] (1965).

Convention Relating to the Status of Refugees (1954). 